\title{
BATASAN USIA PERKAWINAN DALAM HUKUM KELUARGA ISLAM (Perbandingan Antar Negara Muslim: Turki, Pakistan, Maroko dan Indonesia)
}

\author{
Yulia Fatma \\ Pascasarjana Universitas Islam Negeri (UIN) Syarif Hidayatullah Jakarta \\ e-mail: yuliafatma18@yahoo.com
}

\begin{abstract}
Renewal of Islamic family law in the Islamic world is not a new thing, but it has been applied since the 19 th century. The renewal was due to the rise of awareness of the community and scholars that the concepts of fiqh which had been used as references has been left behind from the times. The development of the situation and conditions of the community at that time was one of the causes of the reform of family law. This paper discussess about the family law that applies in several Muslim countries, namely the countries of Pakistan, Turkey, Morocco and Indonesia. Regulatory analysis carried out is by comparing family law that applied in each country regarding the age limit for marriage. The comparison analysis is vertical, horizontal, diagonal and the social conditions of these countries. Each country vertically has a different school handle, then horizontally these countries have provisions regarding the age limits of different marriages, both men and women due to the social conditions of the country itself. While diagonally related to the age limit of marriage, each country still adheres to the school they hold, although explicitly it is not determined how old the marriage is in the classical literature.
\end{abstract}

Kata kunci: Pembaharuan, hukum Keluarga, batas usia perkawinan.

\section{PENDAHULUAN}

Perkawinan merupakan salah satu persoalan dalam Islam yang sejak lama berkorelasi atau berelasi dengan negara, kepemerintahan. Secara historis negara-negara Islam mengatur perkawinan sebagai bagian dari kebijakan politik kependudukan ketika Islam telah menyebar ke wilayah-wilayah lain dan berhubungan dengan budaya hukum warisan Yunani dan Romawi. Kodifikasi hukum keluarga di negaranegara berpendudukan Muslim juga dipengaruhi politik kolonial, utamanya dari Eropa seperti Perancis, Itali dan Belanda yang telah lebih dulu memiliki aturan tentang hukum keluarga. Seperti halnya di Indonesia, negara yang pernah dijajah oleh Hindia-Belanda. Pemerintahannya memberikan izin umat Muslim menggunakan hukum perkawinan Islam yang bersumber dari fiqh dan dicatatkan sebagai perkawinan yang diakui oleh pemerintah kolonial. (Ali, 2015)

Negara sangat dibutuhkan perannya untuk memberikan kebijakan dalam mengatur pembatasan usia perkawinan. Lantaran hal ini sangat terkait dengan kebaikan dan kemaslahatan bagi warganya. Kebaikan yang dilakukan oleh warga negara merupakan suatu kebaikan untuk sebuah negara. Kesejahteraan suatu kaum tercermin dalam kehidupan rumah tangga 
mereka. Tidak terkecuali dengan persoalan batasan usia layak nikah. Pemerintah berhak memberikan batasan, sebab tanpa itu akan muncul situasi buruk dan sulit untuk mengatur regulasi perkawinan warganya.

Begitu pentingnya pembatasan usia nikah demi kemaslahatan bersama, maka setiap negara memiliki batasan usia minimal boleh nikah. Tidak hanya negara Barat saja, namun juga dilakukan oleh negara Muslim bagian Timur. Walaupun banyaknya pro dan kontra dari para tokoh Muslim dengan menyatakan kalau pembatasan usia perkawinan yang digembargemborkan Barat sesungguhnya merupakan "hukuman" bagi "orang yang ingin menjaga kesucian putra putrinya dengan pernikahan sebelum usia 15 tahun", "pengharaman" terhadap "apa yang dihalalkan oleh Allah di dalam kitabNya", "tuduhan keji" terhadap "apa yang dilakukan oleh Rasulullah, para sahabat dan para tabi'in", serta merupakan pengingkaran terhadap kebenaran dalildalil aksiomatik syariat di dalam alQur'an, Sunnah, Ijma' dan amaliyah para sahabat yang menunjukkan bolehnya menikahkan anak-anak perempuan guna menghindari hal-hal buruk yang tak diinginkan". (Ali, 2015)

Dalam sejarahnya, berhubungan dengan proses kodifikasi Undang-undang dan sistem peradilan yang dilakukan oleh timur tengah pada abad ke-19 berada di bawah kekuasaan dari Kolonial Eropa. Pada umumnya negara timur tengah banyak mengadopsi hukum kolonial atau penjajah. (Welchman, 2007) Tidak jauh berbeda dengan negara Asia seperti Malaysia dan Indonesia, kedua negara tersebut juga dipengaruhi oleh penjajah. Setiap Negara Muslim terkait peraturan atau ketentuan hukum keluarga yang telah terkodifikasi khususnya tentang batasan usia minimal boleh nikah memiliki perbedaan. Berkaitan dengan hal tersebut, akan dibahas dalam tulisan ini batasan usia nikah di beberapa negara dengan melakukan perbandingan. Namun hanya membatasi empat negara saja, yaitu Turki, Pakistan, Maroko dan Indonesia.

\section{METODE PENELITIAN}

Adapun metode yang digunakan dalam tulisan ini adalah metode kepustakaan (library method) dengan pendekatan analisis perundang-undangan yaitu dengan melakukan analisis peraturan perundang-undangan dan ketentuan yang berlaku dalam Islam.

\section{BATAS USIA PERKAWINAN}

Perkawinan atau pernikahan merupakan sesuatu yang disyariatkan oleh Nabi Muhammad, yang mana hukumnya termaktub dalam al-Qur'an dan Sunnah. Nikah menurut pendapat fuqaha adalah akad (kontrak) sebagai cara agar sah melakukan hubungan seksual. (Zuhaili, 1989) Pernikahan sangat dianjurkan oleh Islam, maka dari itu pernikahan merupakan sesuatu yang dianggap sakral meskipun di dalam kitabkitab figh klasik mendefeniskan nikah hanya dengan menggunakan kata-kata akad.

Perkawinan adalah al-mitsaq alghalizh (ikatan yang kokoh) yang mempersatukan dua insan, lelaki dan perempuan dalam sebuah komitmen membangun rumah tangga. Perkawinan menciptakan adanya hubungan antara dua keluarga besar dan menjadikan 
kehidupan manusia berkelanjutan dengan menjaga keturunan. Secara sosiologis perkawinan atau rumah tangga disebut sebagai unit-unti terkecil untuk terwujudnya sebuah negara-bangsa. Oleh karena itu, perkawinan merupakan salah satu dari persoalan muamalah.

Berkaitan dengan hukum perkawinan, Wahbah Zuhaili menyatakan bahwa hukum perkawinan menurut para ahli fikih sangat tergantung pada situasi dan kondisi seseorang. (Hosen, 1971) Perkawinan tidak bisa dilakukan kalau tidak memenuhi beberapa persyaratan yang ada. Sahnya perkawinan menurut hukum Islam harus memenuhi rukunrukun dan syarat-syarat, di antaranya; pertama, syarat umum adalah perkawinan tersebut tidak dilakukan yang bertentang dengan larang-larangan yang terdapat dalam ketentuan al-Qur'an. Kedua, syarat khusus yaitu adanya calon pengantin laki-laki dan calon pengantin perempuan, yang mana keduanya adalah syarat mutlak. Calon mempelai tersebut haruslah Islam, aqil baligh, sehat baik rohani maupun jasmani. Batas ideal umur calon mempelai untuk menikah adalah 25 tahun untuk laki-aki dan 20 tahun untuk perempuan atau sekurang-kurangnya 18 tahun walaupun pendapat ini tidak mutlak dijelaskan dalam al-Qur'an ataupun Sunnah. Namun ini harus dilihat dari situasi dan kondisi fisik dan psikis para calon mempelai tersebut. Maksud dari baligh dan berakal adalah dewasa dan dapat dipertanggungjawabkan terhadap sesuatu perbuatan apalagi terhadap akibat-akibat perkawinan, suami sebagai kepala keluarga dan istri sebagai ibu rumah tangga, jadi bukan orang yang di bawah pengampuan (curatele). (Romulyo, 1999)
Keharmonisan rumah tangga suami dan istri bisa dilatar belakangi oleh beberapa faktor selain dari faktor agama, yaitu faktor kedewasaan dan faktor ekonomi. Meskipun kedua faktor tersebut tidak dijelaskan secara jelas dalam alQur'an seperti apa batasan usia yang sudah dikategorikan dewasa dan siap menikah begitu juga halnya ekonomi. Namun, peneliti dalam permasalahan ini lebih fokus membahas faktor kedewasaan berkaitan dengan batas usia boleh nikah.

Pada prinsipnya Islam tidak memberikan batasan pasti berapa umur yang pantas atau umur ideal bagi seseorang untuk melakukan pernikahan. Begitu juga halnya dengan pendapat para ulama yang tidak membahas secara detail terkait umur ideal menikah. Utamanya telah memenuhi syarat dan rukun nikah, maka siapapun boleh dinikahkan. Pandangan seperti ini banyak ditemukan hampir di semua mazhab fiqh. (Ali, 2015)

Dalam al-Qur'an terdapat satu ayat yang menyatakan "dan ujilah anak-anak yatim itu sampai mereka cukup umur untuk menikah. Kemudian jika menurut pendapatmu mereka telah cerdas (pandai memelihara harta)..."QS; An-Nisa [6]. Dalam Tafsir Ayat al-Ahkam (al-Shabuny, 1999), bahwa seorang anak dikatakan baligh apabila anak laki-laki telah bermimpi, sebagaimana telah disepakati ulama bahwa anak yang sudah bermimpi lantas ia junub (keluar mani) maka dia telah baligh, sedangkan ciri-ciri wanita ketika sudah hamil atau haid (Zuhaili, 1989), maka itulah batasan baligh.

Berkaitan dengan batas baligh seorang anak biasanya ditandai dengan tahun, tapi terkadang ditandai dengan tanda yaitu berupa mimpi bagi laki-laki 
dan haid bagi perempuan, sebagaimana yang dijelaskan dalam kitab al-Fiqh 'Ala Madzahib al-Arba'ah. Menurut Hanafi, tanda baligh bagi seorang laki-laki ditandai dengan mimpi dan keluar mani sedangkan perempuan ditandai dengan haid, namun jika tidak ada tanda-tanda bagi keduanya maka ditandai dengan tahun, yaitu 18 tahun bagi laki-laki dan 17 tahun bagi perempuan. Menurut Imam Malik, baligh ditandai dengan tanda keluarnya mani secara Mutlak dalam kondisi menghayal atau sedang tertidur dan biasanya itu sudah terjadi pada anak usia 17 tahun baik laki-laki maupun perempuan. Sedangkan menurut Imam Syafi'i bahwa batasan baligh adalah 15 tahun bagi laki-laki dan 9 tahun bagi perempuan. Kemudian menurut Hambali bagi laki-laki ditandai dengan mimpi atau umur 15 tahun, sedangkan bagi perempuan ditandai dengan haid. (alJaziri, 2003) Para imam mazhab tidak sepakat terhadap batas usia minimal boleh kawin, namun mereka sepakat bahwa baligh menjadi salah satu indikasi kedewasaan seseorang.

Masing-masing fuqaha terutama mazhab yang empat telah menjelaskan terkait kriteria baligh-nya seseorang, yang mana mereka menyamakan masa pubertas (baligh) dengan usia minimal boleh menikah. Dikutip dari Jeremiah J. Bowden, menurut Norman Anderson pubertas seseorang (masa baligh) dapat dilihat dari perubahan fisiknya, tetapi juga bisa ditentukan dengan usia minimum yaitu 12 tahun untuk laki-laki dan tidak ada untuk seorang gadis. Namun rata-ratanya pada usia 15 tahun laki-laki dan perempuan sudah memasuki masa pubertas (baligh). (Bowden, 2013) \begin{tabular}{llr}
\multicolumn{1}{c}{ Muhammad } & Iqbal Siddiqi, \\
menyatakan bahwa seseorang yang & \multicolumn{1}{c}{ y } \\
memiliki kedewasaan dan kecerdasan \\
dapat ditunjukkan dengan adanya
\end{tabular} kemampuan dalam menentukan pilihan yang baik sesuai kepentingannya. Oleh karena itu, menurut Siddiqi usia menikah dan usia yang dikategorikan dewasa adalah terjadi setelah pubertas. Kemudian ia juga menyimpulkan bahwa seorang laki-laki dan perempuan yang belum mencapai pubertas tidak dapat menggunakan pilihannya dalam halhal seksual dan tidak dapat memutuskan apakah dia menyukai dan tidak menyukai perempuan atau laki-laki tertentu untuk menjadi istri atau suami. (Bowden, 2013)

Menurut Imam Ibnu Hazm: bapak tidak boleh mengawinkan anak yang belum baligh. Sekalipun pernah terjadi antara Aisyah dengan Rasulullah, tetapi hal ini merupakan kekhususan bagi Rasulullah. (Syarifuddin, 2011) Pendapat Ibnu Hazm ini sesuai dengan salah satu tujuan kawin, yaitu melanjutkan keturunan. Perkawinan antara orangorang yang belum dewasa tidak akan menghasilkan keturunan. Dengan perkataan lain bahwa apabila perkawinan dilaksanakan oleh orang-orang yang belum dewasa, maka perkawinan itu tidak akan mencapai tujuannya. Berbeda pendapat imam Syafi'i dan imam Hanafi tentang yang dimaksud dengan perempuan yang dewasa. Menurut imam Syafi'i yang dimaksud dengan perempuan yang dewasa ialah perempuan yang telah pernah kawin, sedang menurut imam Hanafi ialah perempuan yang telah baligh. (Mukhtar, 1993)

Perbedaan pendapat ulama dalam menentukan usia baligh, dapat diambil kesimpulan bahwa para fuqaha tidak sepakat dalam menentukan batasan usia 
perkawinan, akan tetapi para ulama fuqaha berpandangan bahwa baligh itu belum tentuk menunjukkan kedewasaan seseorang. Maka daripada itu, mengawinkan anak kecil perempuan yang masih perawan menurut Imam Malik, Imam Hanafi, Imam Syafi'i dan Imam Hambali merupakan hal yang dibolehkan untuk seorang ayah, begitu juga dengan neneknya boleh mengawinkan cucunya yang masih belia, apabila ayah tersebut tidak ada. (al-Jaziri, 2003)

Meskipun dalam al-Qur'an, Sunnah maupun pendapat para fuqaha tidak secara langsung menjelaskan batasan usia perkawinan, namun dapat disimpulkan bahwa seseorang yang hendak menikah adalah yang telah mencapai masa baligh dan memiliki kedewasaan. Tetapi tidak dapat dipungkiri sampai saat ini pernikahan di bawah batasan usia perkawinan atau belum baligh masih dilakukan oleh masyarakat di dunia. Hal tersebut bukan terjadi hanya semata-mata karena adanya keinginan menikah dari kedua belah pihak saja, tapi bisa disebabkan oleh beberapa faktor.

Berkaitan dengan faktor terjadi pernikahan anak atau pernikahan di bawah umur, di antaranya adalah karena faktor ekonomi atau kemiskinan. Kemiskinan merupakan suatu faktor yang umum dan banyak terjadi. Perempuan dianggap sebagai beban ekonomi dalam keluarga karena pendidikan dan kebutuhannya sangat mahal. Oleh karena itu, menurut orang tua menikahkan anak yang masih di bawah umur merupakan salah satu solusi dalam persoalan ekonomi keluarga. Hal ini juga bisa dikategorikan dengan ketidaksetaraan gender, itu terlihat dengan adanya ancaman terhadap hak-hak perempuan. (Rajwani, 2015)

Tingkat kemiskinan yang tinggi, ketidakstabilan sosial dan politik, serta juga pengaruh dari budaya yang kuat merupakan faktor maraknya terjadinya pernikahan anak atau pernikahan di bawah umur. (Paper, 2013) Adanya faktor-faktor tersebut, maka setiap Negara di dunia termasuk Negara Islam melakukan pengkajian ulang terkait hukum keluarga yang berlaku di negaranya, khususnya tentang perkawinan, yaitu batasan usia minimal boleh kawin.

Asas kedewasaan atau kematangan calon mempelai merupakan suatu asas yang sangat penting. (Summa, 2005) Hal tersebut dianggap penting, karena pernikahan yang tidak dilandasi oleh kedewasaan atau kematangan dari calon mempelai akan memberikan dampak yang tidak baik. Kematangan bisa dilihat dari segi fisik maupun psikis (rohani), dengan adanya kematangan akan meminimalisir terjadinya hal-hal yang tidak diinginkan ketika sudah menikah.

Konsekuensi dari pernikahan anak di bawah umur bisa berefek untuk dirinya sendiri, seperti berakibat besar pada kesehatan reproduksi, tidak dapat menyelesaikan pendidikan serta mengalami kekerasan dalam rumah tangga. Pernikahan dini juga berefek terhadap keluarga dan pembangunan negara, seperti penghapusan kemiskinan dan kelaparan, mempromosikan kesetaraan gender dan pemberdayaan perempuan, penurunan angka kematian anak, peningkatan kesehetan ibu dan memerangi HIV/AIDS. (Paper, 2013)

Berhubungan dengan adanya dampak negatif yang ditimbulkan dari 
pernikahan anak di bawah umur tersebut, maka legislator di beberapa negara melakukan amandemen Undang-undang hukum keluarga tentang batasan usia boleh nikah. Undang-undang yang diberlakukan oleh setiap negara Islam di dunia, berbeda-beda dalam menentukan batas usia minimal boleh nikah. Perbedaan tersebut disebabkan al-Qur'an maupun Hadits tidak secara eksplisit menetapkan usia nikah. (Summa, 2005) Selain itu perbedaan penetapan batasan usia minimal boleh nikah juga bisa didorong oleh kondisi sosial negara itu masing-masing serta juga bisa dikarenakan ketidaksamaan sistem hukum yang dianut masing-masing negara tersebut seperti perbedaan mazhab.

Isu mengenai perkawinan anak di bawah umur (zawāj al-qāshirāt) sejak dulu memang selalu menjadi persoalan dan perdebatan hangat di kalangan umat Muslim. Perdebatan tersebut kini semakin melebar dan mencakup berbagai aspek serta melibatkan banyak pihak seperti lembaga-lembaga pemerintahan (eksekutif dan legislatif), dan media-media massa (online, cetak dan televisi) untuk memobilisasi kaum perempuan guna melawan atau mendukung perkawinan anak. (Ali, 2015)

\section{PERBANDINGAN BATASAN USIA PERKAWINAN DI NEGARA MUSLIM}

Pembaharuan hukum Islam di negara-negara Muslim terjadi karena adanya sentuhan antara Islam dan barat, yaitu pada masa penjajahan atau kolonial. Setelah merdeka mereka melakukan reformasi hukum, yang mana dilatar belakangi oleh kesadaran mereka terhadap ketertinggalan masyarakat
Muslim dari kemajuan orang Barat. Tanggapan dan respon umat Islam terhadap Barat pun tentang kemajuan Barat dan kemundur umat Islamberbeda-beda. Pertama, ada yang menolak barat, sehingga pembaharuan mereka adalah pemurnian Islam. Menurut kelompok ini, kemunduran disebabkan oleh umat Islam meninggalkan ajaran Islam yang murni. Sehingga untuk mendapatkan kemajuannya, umat Islam harus kembali kepada ajaran Islam yang murni. (Wahyuni, 2013) Turki merupakan salah satu negara yang melihat bahwa barat merupakan negara maju, sehingga Turki mengadopsi kultur nasional Barat atau pola hidup Barat baik yang berhubungan dengan politik, ekonomi dan sosial, di antaranya adalah persoalan hukum. Sehingga Turki dikenal dengan negara Republik Turki Sekuler. (Yilmas, 1971)

Berkaitan dengan konsep dan metode pembaharuan hukum Islam di Negara-negara muslim, Tahir Mahmood memaparkan bahwa ada yang menggunakan metode intra-doctrinal reform, extra-doctrinal reform dan regulatory reform. Intra-doctrinal reform merupakan pembaharuan hukum Islam yang didasarkan kepada mazhab hukum Islam yang dianut oleh mayoritas masyarakat suatu negara. Seperti Indonesia dengan mazhab Sunny (doktrin Imam Syafi'i). Sedangkan extra-doctrinal reform adalah pembaharuan hukum Islam dengan cara keluar dari pendapat-pendapat mazhab figh yang dianut oleh masyarakatnya, seperti contoh persoalan wasiat wajibah. Kemudian yang dikatakan dengan regulatory reform adalah pembaharuan hukum Islam yang dipengaruhi oleh prosedur hukum barat, ini terjadi dikarenakan adanya persentuhan Islam 
dan Barat, seperti legislasi dan administrsi dengan sistem administrasi modern. (Mahmood, Family Law Reform in The Muslim World, 1972)

\section{Pakistan}

Semula Pakistan merupakan bagian dari India, berdirinya negara Pakistan sebagai jawaban dari seruan yang diajukan oleh orang-orang Islam yang berada di India ketika itu berada di bawah jajahan Inggris. (Mudzhar, 2014) Pada tahun 1947 Pakistan merdeka dengan mendeklarasikan berdirinya Republik Islam Pakistan (Mudzhar, 2014), yaitu Pakistan Timur dan Pakistan Barat. Namun pada tahun 1971 Pakistan Timur menjadi Bangladesh setelah terjadinya perang saudara. (Otto, 2010)

Biro sensus Amerika Serikat memperkirakan populasi Pakistan mencapai 199.085.847 pada tahun 2015, yang setara dengan 2,57\% dari populasi dunia. Mayoritas penduduk Pakistan beragama Islam dengan persentase 97\% dari jumlah penduduk. Sebagian besar dari mereka beraliran Sunni. Pakistan merupakan negara dengan penduduk Muslim terbesar ketiga di dunia setelah Indonesia dan India. Agama lain yang ada di Pakistan adalah Kristen, Hindu, Budha, Jainisme, Zoroastrianisme, dan Baha'i.

(https://id.wikipedia.org/wiki/Pakist an)

Pakistan telah melakukan penggantian konstitusi sebanyak tiga kali, sedangkan Undang-Undang Hukum Keluarganya baru diberlakukan pada tahun 1961, yaitu Muslim Family Law Ordinance (MFLO) of 1961. Meskipun
UU itu dapat dianggap sebagai moderat dibandingkan UU di Turki dan Tunisia, namun di beberapa Pasal yang ada dalam UU ada ancaman hukum kurungan dan denda jika melanggaranya (Mahmood, Personal in Islamic Countries: History, Text, and Comparative Analysis, 1987). Dalam MFLO 1961 dan berbagai peraturan perundangan terkait, ada beberapa amandemen tentang hukum keluarga, di antaranya adalah berhubungan dengan batas usia minimum perkawinan atau boleh nikah di Pakistan. (Mudzhar, 2014)

Berkaitan dengan ketentuan batas usia minimum boleh nikah, Pakistan memiliki Undang-undang sendiri, yaitu UU No. 29 tahun 1929 tentang larangan pernikahan anak (Child Marriage Restraint Act) sebagaimana diamandemen oleh Ordonansi No. 8 tahun 1961. Dalam UU tersebut didefenisikan bahwa anak (child) adalah seseorang yang berumur di bawah 18 tahun bagi laki-laki dan di bawah 16 tahun bagi perempuan. Adapun perkawinan anak ialah perkawinan yang salah satu dari pengantin laki-laki atau perempuan berusia anak-anak. Dalam UU tersebut menggunakan dua istilah anak yaitu child dan minor, minor adalah seseorang baik laki-laki atau perempuan yang berusia di bawah 18 tahun. (Mahmood, 1987)

Negara Pakistan adalah salah satu negara yang menjadikan mazhab Hanafi sebagai pegangan dalam permasalahan hukum khususnya terkait hukum keluarga Islam. (Mahmood, 1972) Pakistan melarang nikah di bawah umur dengan mendasarkan pada al-Qur'an, sebab ajaran al-Qur'an dan Sunnah Nabi 
menuntut syarat dewasa (rusyd) (Shihab, 2004), untuk absahnya transaksi. Padahal akad nikah lebih penting daripada akad yang lain. Konsekuensinya, syarat dewasa untuk perkawinan demikian penting, umur dewasa sempurna (rusyd) pun diperhatikan. Larangan perkawinan di bawah umur pada salah satu pandangan mufassir terhadap ayat alQur'an yaitu Surat An-Nisa' ayat 6 . Meskipun ayat ini pada dasarnya berbicara tentang masa peralihan harta anak yatim, dimana harta mereka diberikan secara penuh kalau sudah rusyd, tetapi ada juga kaitan ayat ini dengan umur kedewasaan untuk boleh menikah (umur minimal boleh nikah). Maka ini yang dijadikan dasar penetapan umur minimal boleh nikah. (Nasution, 2007) Dalam menentukan batasan usia perkawinan ini tidak jauh beda dengan pendapat yag dikemukakan oleh mazhab Hanafi terkait masa baligh bagi laki-laki dan perempuan, yaitu 18 tahun bagi anak laki-laki dan 17 tahun bagi anak perempuan. Pendapat yang digagaskan oleh Hanafi ini adalah batas maksimal dalam masa baligh, sedangkan batasan minimalnya adala 12 tahun untuk laki-laki dan 9 tahun untuk perempuan. (Mahmood, 1972)

Tahir Mahmood menyebutkan bahwa UU di Pakistan melarang terjadinya perkawinan di bawah umur, MFLO mengatur bahwa seorang lakilaki berumur lebih dari 18 tahun yang melakukan akad nikah dengan seorang perempuan berumur di bawah 16 tahun, diancam dengan hukuman penjara paling lama satu bulan atau denda setinggi-tingginya seribu (1000)
Rupee atau kedua-duanya, kecuali kedua belah pihak memiliki bukti yang meyakinkan bahwa keduanya tidaklah melakukan perkawinan di bawah umur (child marriage). (Mahmood, 1987)

Sebelumnya telah dijelaskan, bahwa dalam peraturan perundangan yang berlaku di Pakistan menyebutkan child dan minor. Berkaitan dengan seseorang dalam kategori minor (berumur kurang 18 tahun) melakukan akad nikah dengan seorang di bawah umur, maka orang tua anak atau walinya yang memaksa anaknya menikah, atau karena kelalaian mereka maka orang tua atau walinya itu dapat diancam dengan hukuman penjara paling lama satu (1) bulan atau denda paling banyak seribu (1000) Rupee atau kedua-duanya, dengan pengecualian bahwa perempuan tersebut tidak dihukum penjara. Apabila perkawinan tersebut tetap terjadi, padahal Pengadilan telah memperingatkan wali untuk tidak melangsungkan pernikahan, maka para orang tua atau walinya diancam dengan hukuman penjara paling lama tiga (3) bulan atau denda seribu (1000) Rupee atau keduakeduanya, baik atas inisiatif pengadilan sendiri ataupun aduan dari masyarakat. (Mudzhar, 2014) Komisi di Pakistan memberikan saran untuk melakukan reformasi jangka panjang terhadap Undang-Undang dengan melihat kebutuhan sosial masyarakat. (Connors, 1993)

Meskipun pelarangan perkawinan di bawah umur (childh marriage) telah diberlakukan sejak tahun 1929, problemnya masih berlangsung hingga sekarang. Hal tersebut diakibatkan oleh beberapa 
faktor, di antaranya, yaitu faktor budaya atau adat yang kuat seperti keterlibatan Watta-Satta dan Vani. Watta-Satta merupakan suatu kebiasaan bertukar pengantin antara keluarga, Vani adalah kebiasaan daerah kesukuan Pakistan, dimana gadis-gadis muda secara paksa memungkinkan untuk menikah dengan anggota suku yang berbeda untuk menyelesaikan permusuhan. Keyakinan masyarakat seperti itu memaksa anak perempuan untuk menikah pada usia yang lebih muda. (Rajwani, 2015)

Dampak dari pernikahan dini di Pakistan begitu sangat banyak, terutama untuk perempuan baik secara fisik maupun psikisnya. Secara tidak langsung pernikahan dini yang terjadi di berbagai negara ataupun di Pakistan merengut hak-hak anak, yang kebanyakan adalah hak perempuan.

Selain pengaturan dalam pasalpasal Child Marriage Restraint Act tahun 1929, terdapat sejumlah pasal dalam Hukum Pidana Pakistan lebih kurang berkaitan dengan persoalan perkawinan anak, yaitu Pasal 310-A yang mengancam barnag siapa yang memberikan seorang perempuan untuk dikawini sebagai ganti perdamaian dengan hukuman maksimal sepuluh (10) tahun penjara atau minimal tiga (3) tahun penjara. Pasal 375 yang mendefenisikan perkosaan antara lain sebagai hubungan intim dengan seorang perempuan di bawah umur, baik dengan ataupun tanpa persetujuan., Pasal 376 tentang ancaman hukuman mati bagi pelaku perkosaan, dan Pasal 493-A tentang penipuan yang mengakibatkan terjadinya hubungan intim antara seorang perempuan dan laki-laki (Mudzhar, 2014).

Berhubungan dengan faktor yang menyebabkan terjadinya pernikahan dini di Pakistan, yaitu faktor adat, sebagaimana disebutkan di atas tentang prosesi adat Watta-Satta, Vani yaitu menjadikan perempuan muda sebagai tebusan untuk perdamaian. Hal tersebut di Pakistan dapat dikenakan sanksi pidana setelah diberlakukannya ketentuan Hukum Pidana Pakistan.

\section{Turki}

Turki merupakan salah satu negara Muslim pertama yang menghadapi peradaban barat modern, itu bertepatan pada abad ke-18 (Yilmas, 1971). Pada tahun 1923, Turki memproklamasikan negaranya sebagai negara Republik (Otto, 2010). Turki adalah salah satu anggota pendiri PBB, Organisasi Konferensi Islam (OKI), OECD, dan OSCE serta negara anggota Dewan Eropa sejak tahun 1949. (https://id.wikipedia.org/wiki/Turki)

Turki merupakan negara sekuler tanpa agama resmi, Konstitusi Turki mengatur kebebasan beragama dan hati nurani. Walaupun tidak memiliki agama resmi, dengan jumlah penduduk pada tahun 2017 adalah 79.815 .000 jiwa, $82 \%$ dari keseluruhan populasi menganut agama Islam, $2 \%$ beragama Kristen, $7 \%$ tidak beragama dan 2\% beragama lain (https://id.wikipedia.org/wiki/Turki). Muslim Turki mengarsir kehidupan keberagamaan secara formal dengan berpegang kepada mazhab Hanafi hingga tahun 1926, 
sebelum ada kebijakan legislasi Undang-Undang yang dikodifikasi secara elektikal. Undang-undang Sipil Islam atau yang disebut Majallat alAhkam al-'Adliyah, sebagian materinya didasarkan mazhab Hanafi, yang sebelumnya telah dirancang semenjak tahun 1876. (Mudzhar, 2003) Dalam amandemen hukum keluarga yang dilakukan oleh Turki pada tahun 1926 terkait ketentuan-ketentuan tentang pertunangan (masalah taklik talak), batsan usia minimal boleh nikah, poligami, pencatatan perkawinan, perceraian dan waris. Proses amandemen di Turki terjadi sebanyak enam kali dari tahun 1933-1965. (Mahmood, 1987)

Tahun 1937, prinsip sekularisme dimasukan ke dalam konstitusi Turki. Dalam soal perkawinan, hukum perkawinan tidak lagi dilakukan sesuai dengan syari'at Islam, tetapi dilakukan sesuai dnegan hukum sipil (code civil) yang diadopsi dari Swiss (Swiss Civil Code). (Mudzhar, 2003)

Berkaitan dengan ketentuan batasan usia minimal boleh nikah, dalam Undang-undang Turki (The Ottoman Law Of Family Right 1917 "capacity to marry" act 4-8) mengatur, bahwa umur minimal seseorang yang hendak melaksanakan perkawinan adalah 18 tahun bagi laki-laki dan 17 tahun bagi perempuan. Pengadilan juga dapat mengizinkan pernikahan pada usia 15 tahun bagi laki-laki dan 14 tahun bagi perempuan setelah mendapat izin orang tua atau wali. Dalam menentukan batasan usia perkawinan ini tidak jauh beda dengan pendapat yag dikemukakan oleh mazhab Hanafi terkait masa baligh bagi laki-laki dan perempuan, yaitu 18 tahun bagi anak laki-laki dan 17 tahun bagi anak perempuan. Pendapat yang digagaskan oleh Hanafi ini adalah batas maksimal dalam masa baligh, sedangkan batasan minimalnya adalah 12 tahun untuk laki-laki dan 9 tahun untuk perempuan. (Mahmood, 1972)

Berkembangnya zaman, maka terjadi pergolakan politik di Turki sehingga juga mempengaruhi stabilitas perundang-undangan. Pada akhirnya Turki mengadopsi peraturan perundangundangan Swiss (The Swiss Civil Code tahun 1926) sehingga peraturan tentang batasan usia minimal boleh nikah juga berubah, yang pada awalnya batasan umur laki-laki adalah 18 tahun menjadi 17 tahun begitu juga perempuan menjadi 17 tahun yang tertera dalam Undang-Undang Sipil Turki 1926 adalah "seorang laki-laki dan perempuan tidak dapat menikah sebelum berumur 17 tahun. Kecuali dalam kasus-kasis tertentu, pengadilan mengijinkan terjadinya pernikahan umur 16 tahun bagi laki-laki dan perempuan, setelah adanya konsultasi/ ijin wali atau orang tuanya. (The Turkish Civil Code 1926 (Undang-Undang Sipil Turki 1926)

Perubahan tersebut juga dilatar belakangi oleh bias gender yaitu banyaknya tuntutan kesetaraan antara kaum perempuan dan laki-laki. Terhadap calon mempelai yang tidak memenuhi sebagaimana umur perkawinan dalam Undang-undang tersebut calon mempelai atau walinya boleh mengajukan dispensasi nikah. (Mahmood, 1972)

\section{Maroko}

Maroko memperoleh kemerdekaan pada tahun 1956, populasi penduduk 
Maroko sekitar 33 juta jiwa. Sebagian besar penduduk Maroko adalah Berber dengan pengaruh Arab. Bahasa resmi yang digunakan di Maroko adalah bahasa Arab dan Berber. Sedangkan bahasa Perancis mereka gunakan dalam perdagangan dan administrasi publik. Hampir seluruh penduduk Maroko adalah muslim (98,7\%), sisanya Kristen $(1,1 \%)$ dan Yahudi (0,2\%). (Otto, 2010)

Maroko adalah negara yang menganut sistem pemerintahan dengan model kerjaan (Kingdom of Marocco) dengan mendasarkan pada konstitusi (Constitutional monarchy). Dalam konteks hukum Islam, Maroko menganut mazhab Maliki, yang menjadikan sebagai salah satu sumbersumber hukum nasional. Hal ini terlihat dengan ketentuan-ketentuan terkait hukum perkawinan yang ada dalam kitab al-Mudawwanah sebagai dasar fiqh mazhab Maliki. (An-Na'im, 2002)

Sebelum tahun 1957, hukum perkawinan dan keluarga yang berlaku di Maroko berdasarkan dengan hukum Islam atau fiqh. Namun, semenjak negara itu memulai melakukan kodifikasi hukum Islam di era tahun 1957-1958, selain hukum Islam yang menjadi bahan penyusunan kodifikasi hukum keluarga tersebut, juga dipengaruhi oleh hukum barat, terutama dari Perancis. Maroko melakukan reformasi terhadap hukum keluarga, pertama dilakukan pada tahun 1957 yaitu amandemen hukum hukum keluarga dan terakhir tahun 2004 tentang perubahan hukum keluarga. Reformasi ini mengidentifikasikan bahwa hukum Islam sama seperti hukum sipil dan common law yang dapat beradaptasi dengan kondisi sosial dan ekonomi masyarakat yang berubah (Maksum, 2016). Ketentuan terkait hukum keluarga di Maroko disebut dengan Mudawwanah al-Ahwal al-Syakhshiyah (The Code of Personal Status 1958). (Mahmood, 1972) Setelah terjadinya reformasi pada tanggal 3 Februari 2004 berubah menjadi Mudawwanah al-Ahwal al-Syakhsiyyah al-Jiddah fi al-Maghrib atau Mudawwanah al-Usrah.

Amandemen Undang-Undang Perkawinan yang dilakukan Maroko pada tahun 2004, sebagai berikut. Pertama, menjujung harkat dan martabat perempuan dalam keluarga, yang mana suami dan istri memiliki tanggung jawab yang sama untuk membina rumah tangga. Kedua, hakhak perempuan untuk melakukan perbuatan hukum sesuai dengan kehendaknya selama perkawinan dilindungi undang-undang. Ketiga, usia minimum untuk dapat menikah antara laki-laki dan perempuan ditetapkan sama, yaitu minimal 18 tahun. Meskipun demikian, dispensasi usia perkawinan dapat diberikan oleh hakim kepada calon suami dan istri yang telah berusia enam belas tahun. Izin pengadilan tersebut harus dimintakan oleh kedua orang tua atau walinya (Pasal 19-22 Undang-undang Keluarga Maroko). Keempat, pembatasan poligami. Kelima, hak perempuan untuk mengajukan cerai dan hak-hak yang harus diterimanya. keenam, dapat dilakukan pemisahan harta antara suami dan istri berdasarkan kesepakatan bersama. (Maksum, 2016) Amandemen Hukum Keluarga ini mengakomodir kesetaraan 
gender yang menyatakan tidak adanya perbedaan antara laki-laki dan perempuan.

Hal tersebut terlihat sekali, yang mana sebelumnya dalam Mudawwanah alAhwal al-Syakhshiyyah mengatur batasan usia boleh nikah 18 tahun bagi laki-laki dan 15 tahun bagi perempuan. (AnNa'im, 2002) Namun dengan adanya reformasi di tahun 2004, maka penetapan batas usia perkawinan menjadi 18 tahun bagi calon laki-laki dan perempuan sebagaimana tuntutan kesetaraan antara hak laki-laki dan perempuan di negara tersebut.

Sebagaimana dalam Mudawrwanah alUsrah tersebut tidak memberikan denda terhadap orang yang melakukan pernikahan di bawah umur. Apabila seseorang yang masih di bawah umur ingin melangsungkan pernikahan dibolehkan dengan syarat ada izin dari orang tua atau walinya dan meminta dispensasi ke Pengadilan.

\section{Indonesia}

Indonesia merupakan negara kesatuan dan bentuk pemerintahannya adalah Republik Presidensial multi partai yang demokratis. Indonesia merupakan negara yang pernah dijajah oleh Belanda, sehingga peraturan perundangan yang berlaku di Indonesia ada dipengaruhi oleh hukum Belanda. Berdasarkan proyeksi Badan Perencanaan Pembangungan Nasional (Bappenas) jumlah penduduk Indonesia pada tahun 2018 mencapai 265 juta jiwa.

Mayoritas penduduk Indonesia memeluk agama Islam dengan persentase $85,2 \%$, yang menjadikan Indonesia negara dengan penduduk muslim terbanyak di dunia. Sisanya beragama Protestan (8,9\%), Katolik
(3\%), Hindu (1,8\%), Buddha $(0,8 \%)$ dan lain-lain (https://id.wikipedia.org/wiki/Indon esia ).

Penetapan untuk usia perkawinan terdapat dalam Undang-Undang Perkawinan 1974 pada Pasal 7 (1), perkawinan hanya diizinkan apabila calon mempelai laki-lakinya mencapai umur 19 tahun dan calon mempelai perempuan telah mencapai 16 tahun. Apabila calon mempelainya belum cukup umur untuk melaksanakan perkawinan, maka dapat mengajukan dispensasi nikah ke Pengadilan sesuai dengan pasal 7 (2). Dalam hal penyimpangan dalam ayat (1) pasal ini dapat minta dispensasi kepada Pengadilan atau pejabat lain yang diminta oleh kedua orang tua pihak laki-laki dan perempuan. (Huda, 2017)

Dalam Kompilasi Hukum Islam (KHI) pasal 15 ayat (1) menyebutkan perkawinan hanya diizinkan jika pihak laki-laki sudah mencapai usia 19 tahun dan pihak perempuan sudah mencapai umur 16 tahun, tidak jauh beda dengan Undang-Undang Perkawin 1974. Hal ini didasarkan pasa pertimbangan kemaslahatan keluarga dan rumah tangga perkawinan. Oleh karena itu, calon suami dan istri harus sudah siap jiwa raganya, agar dapat mewujudkan tujuan perkawinan secara baik dan sehat. Untuk itu harus dicegah adanya perkawinan antara calon suami istri yang masih di bawah umur atau pernikahan

dini. (http:/ / repository.uinmalang.ac.id/1332/2/1332.pdf)

Penetapan usia boleh nikah dalam Pasal ini didasarkan pada mazhab dominan yang dipegang oleh 
masyarakat Indonesia yaitu mazhab Syafi'i. Dalam mazhab Syafi'i, ditetapkan bahwa batasan usia seseorang dikategorikan baligh apabila telah mencapai usia 15 tahun baik lakilaki maupun perempuan, disertai dengan tanda-tanda haid bagi perempuan dan mimpi basah untuk laki-laki. (Mughniyah, 1998)

Di Indonesia sendiri faktor-faktor penyebab terjadinya pernikahan di bawah umur adalah faktor ekonomi (kemiskinan), faktor sosial (keinginan menaikan status sosial), faktor pendidikan (kurangnya pendidikan), serta disebabkan hamil sebelum menikah (RI, 2013). Dampak yang terjadi dari pernikahan dini di Indonesia sesuai dengan datadata yang didapatkan oleh Kementerian Agama dalam penelitian di beberapa daerah, terdapat dampak sosial seperti tingginya tingkat keretakan rumah tangga yang berakhir dengan perceraian atau perempuan yang mendapatkan kekerasan baik fisik maupun psikis. Hal tersebut bisa berdampak pada kesehatan, yaitu kesehatan reproduksi perempuan dan menyebabkan tingkat kematian semakin meningkat baik tingkat kematian ibu maupun anak (RI, 2013). Tentu fakta sosial mempunyai banyak peran dalam masalah ini. Banyaknya kasus pernikahan dini yang berakhir dengan tragis cukup memberikan aspirasi atas urgensitas pembatasan usia kawin.

Isu terakhir terkait batasan usia boleh nikah di Indonesia yaitu adanya permohonan dari pemohon kepada Mahkamah Konstitusi (MK) untuk melakukan uji materil terhadap pasal 7
Undang-Undang Perkawinan tentang batas usia nikah. Sekelompok warga negara berpandangan bahwa batas usia nikah yang tercantun dalam UndangUndang No. 1 Tahun 1974 dapat medatangkan kerugian, di antaranya yaitu diskriminasi untuk perempuan, terutama dalam masalah kesehatan. Maka para pihak tersebut mengajukan permohonan kepada MK. Dengan pertimbangan hakim, menyebutkan bahwa batas usia nikah antara laki-laki dan perempuan yang terdapat dalam Undang-Undang Perkawinan dapat menimbulkan diskriminasi. Oleh karena itu MK memberikan tenggang waktu kepada Badan Legislatif untuk melakukan revisi batas usia nikah paling lama tiga tahun

https://www.republika.co.id/berita/n asional/news-analysis/18/12/14).

Berkaitan hal tersebut banyak pro dan kontra yang muncul di kalangan masyarakat, baik para akademisi, kesehatan dan para ulama.

\section{ANALISIS PERBANDINGAN}

Menurut Atho Mudzhar, ada tiga tataran dalam melakukan analisis perbandingan terkait hukum keluarga di negara Islam, yaitu secara horizontal, vertikal dan diagonal. (Mudzhar, 2014) Secara vertikal, jika diperhatikan sejarah dinamika hukum Islam di Indonesia memiliki karakteristik dominan diwarnai oleh kepribadian Arab (Arab Oriented) dan lebih dekat kepada mazhab Syafi'i. Hal ini dapat dilihat dari kitab-kitab rujukan yang dipakai oleh para ulama kebanyakan menggunakan kitab-kitab fiqh syafi'iyyah (An-Na'im, 2002). Mazhab Syafi'i menetapkan batasan usia baligh ketika 
sudah berusia 15 tahun bagi laki-laki dan perempuan (batas minimal pubertas pada laki-laki dan perempuan).

Sedangkan negara Pakistan merupakan negara yang cenderung dan dominan menggunakan mazhab Hanafi, (An-Na'im, 2002) sama dengan negara Turki yang juga menggunakan mazhab Hanafi, meskipun sekarang Turki sudah memiliki pandangan sistem pemerintahan dan hukum sendiri dengan mengadopsi hukum Eropa.

Kendati, Turki sebelum melakukan pembaharuan hukum keluarga, Turki mempunyai peran penting dalam sejarah hukum Islam, terutama di Asia Barat. Hukum perdata di Turki pada awalnya didasarkan pada Mazhab Hanafi, namun kemudian juga menampung mazhabmazhab lain, seperti dalam Majallah alAhkam al Adhiyah yang telah dipersipkan semenjak tahun 1876, namun di dalamnya tidak terdapat aturan tentang hukum keluarga (Mahmood, 1987). Mazhab Hanafi menetapkan masa minimal pubertas atau masa seseorang bisa dikategorikan dewasa dan dapat bertanggung jawab pada usia 18 tahun untuk laki-laki dan 17 tahun untuk perempuan. Walaupun Turki banyak mengalami perubahan termasuk mendeklarasikan negara sebagai negara sekuler, akan tetapi di dalam UndangUndang Turki khususnya mengenai usia boleh nikah tetap mengadopsi mazhab Hanafi.

Maroko merupakan negara yang bermazhab Maliki, negara tersebut menerapkan prinsip-prinsip hukum mazhab Maliki dalam pengadilan Syari'ah (Mahmood, 1972). Pembaharuan hukum Maroko antara lain tercermin dalam rancangan (draft) Undang-Undang
Hukum Keluarga, Mudawwanah al-Ahwal al-Syakhshiyyah pada tahun 1957-1958 dan Mudawwanah al-Usrah 2004.

Para ahli hukum Maroko melakukan finalisasi draf Hukum Keluarga, sumbersumber yang dijadikan rancangan adalah: (a) prinsip-prinsip berbagai Mazhab fiqh, khususnya mazhab Maliki, (b) doktrin Maliki tentang Mashlahah Mursalah, (c) Legalisasi yang diterapkan di negerinegeri Muslim (Mahmood, 1987). Berkaitan batas usia boleh nikah yang diterapkan oleh Maroko tidak selaras dengan batas usia baligh atau dewasa yang dicantumkan oleh mazhab Maliki, selain dengan tanda-tanda baligh yang telah dijelaskan sebelumnya, mazhab Maliki juga memberikan kisaran usia yang dikategorikan dengan dewasa dan siap menikah yaitu 17 tahun. Namun Maroko dalam penetapan batasan usia minimal boleh nikah hampir serupa dengan Indonesia yaitu berkiblat pada mazhab Syafi'i dan Hambali. Maroko juga mengharuskan adanya izin dari wali apabila kedua calon mempelai kurang dari 21 tahun.

Perbedaan mazhab yang dijadikan sebagai tempat bersandarnya negara-negara tersebut, maka di sana juga terlihat perbedaan batas usia boleh nikah yang berlaku menurut Undang-Undang Hukum Keluarga masing-masing Negara. Namun perbedaan itu tidak terlalu signifikan dan jauh, hanya sekitar satu atau dua tahun.

Selanjutnya secara horizontal, Indonesia sendiri terkait batasan usia minimal boleh nikah diatur dalam Pasal 7 ayat (1) (Undang-Undan Perkawinan Nomor 1 Tahun 1974), yang menyatakan bahwa batas usia minimal untuk kawin atau nikah yaitu 19 tahun untuk pria dan 
16 tahun untuk perempuan, beda hal dengan Pakistan, Turki dan Maroko. Pakistan menetapkan batas usia boleh nikah 18 tahun untuk laki-laki dan 16 tahun untuk perempuan (Ordonansi Nomor 8 Tahun 1961 (Muslim Family Law Ordinance 1961)). Sedangkan di Turki batas usia boleh nikah 17 bagi laki-laki dan 15 bagi perempuan dan di Maroko 18 tahun untuk laki-laki dan perempuan (Mudawwanah al-Usrah 2004).

Perbandingan batasan usia boleh nikah di setiap negara yang telah dijelaskan sebelumnya berbeda-beda. Kalau dilihat dari angka-angka menunjukkan bahwa batas umur untuk nikah di Indonesia relatif tinggi untuk laki-laki yaitu 19 tahun, sedangkan di Negara-negara lain hanya rata-rata menetapkan 18 tahun.

Batas usia menikah di dunia Islam dan negara-negara berpenduduk Muslim ratarata berkisar antara 15-21 tahun. Untuk kaum laki-laki rata-rata usia nikah adalah 16 hingga 21 tahun, sementara usia nikah bagi perempuan rata-rata berkisar antara 15-18 tahun. Jadi, usia nikah perempuan pada umunya lebih muda antara 1 hingga 2 tahun lebih dibandingkan laki-laki, kecuali negara Maroko yang tidak ada perbedaan antara laki-laki dan perempuan. Menurut Amin Summa perbedaan ini terjadi karena al-Qur'an maupun Hadits tidak secara eksplisit menjelaskan atau menetapkan usia nikah. (Summa, 2005)

Kemudian secara diagonal, ketentuan batas usia boleh nikah di Indonesia, Pakistan, Turki dan Maroko tidak dipengaruhi oleh faktor sekuler dan liberal, karena negara-negara tersebut dalam menetapkan batas usia nikah sesuai dengan mazhab yang dominan, baik secara intra doctrinal reform maupun extra doctrinal reform. Terkait permbatasan usia tersebut melihat kepada faktor mashlahah dan mafsadahnya, dengan menginterpretasikan ayat-ayat al-Qur'an dan Hadits karena di dalam keduanya tidak menjelaskan secara eksplisit terkait batas usia minimal nikah.

Perihal denda atau hukuman bagi yang melakukan pelanggaran batas usia boleh nikah tidak berlaku di Indonesia, Turki dan Maroko. Pelanggarnya tidak dikenakan sanksi apapun dan pernikahannya tetap sah. Sedangkan di Pakistan bagi pelanggar atas batas usia minimal boleh nikah dapat dikenakan sanksi penjara selama bulan dan denda paling banyak 1000 Rupee. Kemudian bagi mereka yang memimpin pelaksanaan atau mengarahkan terlaksananya Child Marriage itu diancam dengan hukuman penjara selama-lamanya satu bulan atau denda paling banyak 1000 Rupee. (Mudzhar M. A., 2017)

Implementasi hukum keluarga Pakistan juga masih berhadapan dengan adat yang masih kuat. Sebagian pengaturan hukum keluarga itu telah beranjak dari kitab fikih, bahkan memberikan ancaman hukum penjara dan /atau denda atau pelanggarannya, karenanya tidak dapat disebut konservatif meskipun tidak dapat pula dikatakan sekuler seperti yang dilakukan Turki dan Tunisia. (Mudzhar, 2014)

Selain dari tiga bentuk analisis perbandingan yang ditawarkan oleh Atho Mudzhar, ada satu bentuk lagi analisis perbandingan yaitu secara sosial politik. Adanya batas usia layak nikah yang diatur dalam UndangUndang pada setiap 
negara -sebagaimana yang telah dijelaskan sebelumnya- disebabkan oleh kultur dan problem-problem sosial di masing-masing negara. Tidak bisa dipungkiri hal tersebut juga disebabkan oleh kondisi politik. Seperti di Maroko, pembaharuan-pembaharuan hukum di Maroko didorong oleh para pelopor gender, yaitu adanya kesetaraan antara laki-laki dan perempuan tanpa adanya perbedaan. Oleh karena itu Maroko menetapkan batas usia nikah pada umur 18 tahun laki-laki dan perempuan. (Mudawwanah al-Usrah 2004) Begitu juga halnya dengan negara-negara lainnya.

Khususnya di Indonesia, baru-baru ini adanya putusan Mahkamah Konstitusi (MK) yang mengabulkan gugatan uji materiil Undang-Undang No.1 Tahun 1974 terkait batas usia menikah, yang mana dalam pertimbangan putusan MK tersebut menyebutkan bahwa batas usia nikah yang terdapat dalam Pasal 7 Undang-Undang Perkawinan bisa menimbulkan diskriminasi terhadap perempuan. dalam pertimbangan hakim juga mencantumkan bahwa perkawinan anak dinilai sangat mengancam dan berdampak negatif terutama pada aspek kesehatan. Sehingga MK memberikan tenggang waktu kepada badan legislatif untuk melakukan perubahan terhadap Undang-Undang Perkawinan terkhususnya terkait batas usia menikah selama 3 tahun. Permohonan ini diajukan karena disebabkan tingkat pernikahan anak di Indonesia meningkat (https://www.republika.co.id/berita/nas ional/news-analysis/18/12/14).

Tujuan adanya aturan batasan usia perkawinan adalah untuk kemaslahatan umat. Apabila tidak diatur terkait usia boleh nikah baik laki-laki maupun perempuan, maka akan marak terjadinya pernikahan dini. Sebagaimana telah dijelaskan sebelumnya bahwa bahaya atau dampak yang terjadi dari pernikahan dini tidak hanya pada keluarga kecil saja akan tetapi juga untuk perkembangan ekonomi dan sosial masyarakat luas. Oleh karena itu, fungsi dari pembatasan tersebut adalah mengutamakan kemashlahatan dengan menolak mudharat yang ada. (Raysuni, 2010). Untuk mencapai kemashlahatan umum merupakan salah satu tujuan syari' dalam membuat syari'at (ketentuan). Para ulama menilai bahwa maqashid syariah merupakan aspek terpenting yang harus diperhatikan dalam penentuan hukum (instinbath al-hukm). 'Abd al-Majid alNajjar menegaskan bahwa setiap hukum yang diputuskan seorang mujtahid tidak boleh keluar dan bertentangan dengan maqashid syari'ah itu sendiri. (al-Najjar, 2008) Begitu juga dengan penetapan aturan pembatasan usia perkawinan, maka para pembuat Undang-undang baik ulama maupun ahli hukum serta ahli dalam bidang ilmu pengetahuan lainnya harus memperhatikan kemashlahatan umum dan tidak keluar dari ketentuan yang sudah ada.

Tabel perbedaan usia boleh nikah di Turki, Pakistan, Maroko dan Indonesia, sebagai berikut:

Tabel Perbedaan Batas Usia Nikah

\begin{tabular}{|l|c|c|}
\hline \multirow{2}{*}{ Negara } & \multicolumn{2}{c|}{ Batasan Usia Menikah } \\
\cline { 2 - 3 } & Laki-laki & perempuan \\
\hline Turki & 17 & 15 \\
\hline Pakistan & 18 & 16 \\
\hline Maroko & 18 & 18 \\
\hline Indonesia & 19 & 16 \\
\hline
\end{tabular}




\section{KESIMPULAN}

Perkawinan dalam pandangan Islam merupakan fitrah kemanusian yang sangat dianjurkan bagi umat Islam karena menikah merupakan naluri kemanusian yang harus dipenuhi dengan jalan yang sah, agar tidak mencari jalan kesesatan yang menjerumuskan ke lembah hitam. Perintah perkawinan dalam Islam tertuang dalam al-Qur'an dan Hadits Nabi Muhammad. Isu nikah muda sering menjadi polemik dan kontroversi dalam masyarakat dikarenakan masih ada asumsi bahwa hal itu dianjurkan agama.

Istilah dan batasan nikah di bawah umur dalam kalangan pakar hukum Islam sebenarnya masih terjadi perbedaan. Nikah muda dalam persepsi ulama adalah pernikahan yang dilakukan sebelum mencapai masa baligh. Syariat Islam tidak membatasi usia tertentu untuk menikah, namun secara implisit syariat menghendaki orang yang akan menikah adalah benar-benar orang yang sudah siap mental, fisik dan psikisnya, dewasa dan faham arti sebuah pernikahan yang merupakan bagian dan ibadah.

Kontroversi muncul menyangkut batasan kedewasaan seseorang untuk boleh menikah yang berimplikasi terhadap tidak adanya kebebasan atas pernikahan di bawah umur dalam kaca mata ini. Hal ini dapat dilihat dari berbagai peraturan yang berlaku di berbagai Negara muslim di dunia. Dalam penetapan batasan umur tersebut setiap negara berbeda dalam menetapkan usia anak boleh menikah. Hal tersebut bisa didasari karena berbedanya mazhab yang dipegang oleh Negara tersebut atau dilihat dari kondisi sosial Negara itu.

\section{DAFTAR PUSTAKA}

Al-Jaziri, Abd al-Rahman. (2003). Kitab alFigh Ala Madzahib al-Arba'ah. Beirut: Dar al-Kutub al-'Ilmiyyah.

Al-Najjar, Abdul Majid. (2008). Maqashid Syari'ah bi Ab'ad Jadidah. Tt:Dar alGharb al-Islami.

Al-Shabuny, Muhammad Ali. (1999). Tafsir al-Ahkam min al-Qur'a., Beirut: Dar al-Kutub al-'Ilmiyyah.

Ali, Mukti, dkk. (2015). Fikih Kawin Anak: Membaca Ulang Teks Keagamaan Perkawinan Usia Anak-Anak. Rumah Kitab.

An-Na'im, Abdullah A. (2002) Islamic Family Law in a Changing World: A Global Resource Boo. London: Zet Books Ltd.

Bowden, Jeremiah J. (2013). Marriageable Age in Islam: A Study on Marriageable Age Law and Reforms in Islamic Law, LUX: A Journal of Transdisciplinary Writing anf Research from Claremont Graduate University. Volume 2.

Hosen, Ibrahim. (1971). Figh Perbandingan Dalam masalah Nikah, Talaq, Rujuk dan Hukum Kewarisan. Jakarta: Yayasan Ihya 'Ulumuddin Indonesia.

Huda, Miftahul. (2017). Ragam Bangunan Perundang-Undangan Hukum Keluarga Di Negara-Negara Muslim Modern (Kajian Tipologi). AlManahij, Vol. XI, No.1, Juni.

Kementerian Agama RI. (2013). Menelusuri Makna di Balik Fenomena Perkawinan Di Bawah Umur Dan Perkawinan Tidak Tercatat. Jakarta: Puslitbang Kehidupan Keagamaan.

Mahmood, Tahir. (1972). Family Law Reform in The Muslim World. New Delhi: Tripathi. 
Mahmood, Tahir. (1987). Personal in Islamic Countries: History, Text, and Comparative Analysi., New Delhi: Academy of Law and Religion.

Mallat, Chibili and Jane Connors. (1993). Islamic Family Law. London: Graham and Trotman,.

Maksum, Muhammad. (2016). Kedudukan Syariah Sebagai Sumber Hukum Positif: Kajian Awal atas Hukum Perkawinan, Ekonomi Islam, dan Hukum Ketenagakerjaan di Indonesia dan Marok. Istinbāth Jurnal Hukum Islam. Vol. 5, No. 2. Desember.

Mudzhar, Atho. (2014). Esai-Esai Sejarah Sosial Hukum Islam. Yogyakarta: Pustaka Pelajar.

Mudzhar, Atho dan Khairuddin nasution. (2003). Hukum Keluarga di Dunia Islam Modern: Studi Perbandingan Dan Keberanjakan UU Modern dan KitabKitab Fikih, Jakarta: Ciputat Press.

Mudzhar, Atho. (2014). Hukum Keluarga di Pakistan (Antara Islamisasi dan Tekanan Adat). Al-'Adalah, Vol. XII, No. 1. Juni.

Mudzhar, Muhammad Atho dan Muhammad Maksum. (2017). Fikih Responsif. Yogyakarta: Pustaka Pelajar.

Mughniyah, Muhammad Jawad. (1998). Al-Figh 'Ala al-Madzahib al-Khamsah. Teheran:Muassasah al-Shadiq li alThiba'ah wa al-Nasyri.

Mukhtar, Kamal. (1993). Asas-Asas Hukum Islam tentang Perkawinan. Jakarta: Bulan Bintang.

Nasution, Khoiruddin. (2007). Metode Pembaharuan Hukum Keluarga Islam Kontempore. UNISIA, Vol. XXX, No. 66, Desember.
Otto, Jan Michiel. (2010). Sharia Incorporated. Amsterdam: Leiden University Press.

Paper, White. (2013). Child Marriage in the Midlle East and North Africa, International Centre For Missing $\mathcal{E}$ Exploited Children.

Rajwani, Armish Aziz (2015). Nazixh Hussain Ali Pachani. Early marriage of girls in Pakistan, i-manager's journal nursing, vol. 5, No. 3. Agustus-Oktober.

Raysuni, Ahmad. (2010). Madkhal ila Maqasid Shariah. Kairo: Dar alKalimah.

Romulyo, Mohd. Idris. (1999).Hukum Perkawinan Islam (Studi Analisis dari Undang-undang Nomor 1 Tahun 1974 dan Kompilasi Hukum Islam), Jakarta: Bumi Aksar.

Shihab, M. Quraish. (2004). Tafsir AlMisbah, Jakarta: Lentera Hati.

Summa, Muhammad Amin. (2005). Hukum Keluarga Islam di Dunia Islam, Jakarta: PT RajaGrafindo Persada.

Syarifuddin, Amir. (2011). Hukum Perkawinan Islam di Indonesia, Jakarta: Kencana.

Wahyuni, Sri. (2013 M/1435H). Pembaharuan Hukum Keluarga Islam di Negara-Negara Muslim, $\mathrm{Al}$ Ahwāl, Vol. 6, No. 2.

Welchman, Lynn, (2007). Women And Muslim Family Laws in Arab States: a Comparative Overview of Textual Development, Amsterdam: Amsterdam University Press.

Yilmas, Ihsan. (1971). Muslim Laws, Politics and Society in Modern Nation States: Dynamic Legal Pluralisms in England, Turkey and Pakistan, England: Ashgate. 
Zuhaili, Wahbah. (1989). Figh Islam wa Adilatuhu. Jilid 7, Damaskus: Dar Fikr.

\section{Internet}

https:// www.republika.co.id/berita/inte rnasional/timurtengah/18/04/27/p7szou382maroko-berjuang-kurangipernikahan-anak

https:// www.republika.co.id/berita/nasi onal/news-analysis/18/12/14

https://id.wikipedia.org/wiki/Indonesia https:// databoks.katadata.co.id/datapubl ish

https://id.wikipedia.org/wiki/Turki, https://id.wikipedia.org/wiki/Pakistan

Sudirman. Pembatasan Usia Minimal Perkawinan Upaya Meningkatkan
Martabat

Perempuan, http:/ / repository.uinmalang.ac.id/1332/2/1332.pdf

\section{Undang-undang}

Kompilasi Hukum Islam (KHI)

Mudawwanah al-Usrah 2004

The Turkish Civil Code 1926 (UndangUndang Sipil Turki 1926)

Undang-Undang Nomor 29 Tahun 1929 tentang larangan pernikahan anak (Child Marriage Restraint Act) diamandemen oleh Ordonansi Nomor 8 Tahun 1961 (Muslim Family Law Ordinance 1961)

Undang-Undang Perkawinan Nomor 1 Tahun 1974 